\title{
Practices and Challenges of Classroom-Based Reading Assessment: A Literature Review
}

\author{
Nur Hafizah Shaari, Maslawati Mohamad* \\ Faculty of Education, Universiti Kebangsaan Malaysia, Bangi, Malaysia \\ Email: hafizahshaari29@gmail.com, *maslawati@ukm.edu.my
}

How to cite this paper: Shaari, N. H., \& Mohamad, M. (2020). Practices and Challenges of Classroom-Based Reading Assessment: A Literature Review. Creative Education, 11, 1962-1972.

https://doi.org/10.4236/ce.2020.1110143

Received: August 30, 2020

Accepted: October 17, 2020

Published: October 20, 2020

Copyright (อ 2020 by author(s) and Scientific Research Publishing Inc. This work is licensed under the Creative Commons Attribution International License (CC BY 4.0).

http://creativecommons.org/licenses/by/4.0/ (c) (i) Open Access

\begin{abstract}
Assessment nowadays has becoming an essential part of effective teaching and learning. To compete in the global world, the Malaysian Education has shifted the norms of summative assessment to a more formative approach, which is classroom-based assessment, where learning development of the learners are being focused on instead of the outcome. While classroom-based assessment offers a wide opportunity for the educators to choose the methods and approach they think appropriate and effective when assessing students' reading, yet majority of the English language educators find it difficult in dealing with classroom-based reading assessment. In accordance to that, this paper provides a literature review on 1) the methods preferred by the ESL educators in practicing classroom-based reading assessment and 2) the challenges faced by ESL educators in implementing classroom-based reading assessment. In assessing reading, education authorities as well as educators may work together in finding the solution.
\end{abstract}

\section{Keywords}

Classroom Assessment, Assessment Practices, Reading Literacy, Reading Skills, Reading Assessment, English as a Second Language (ESL)

\section{Introduction}

English language has been crowned in today's world as one of the significant languages mainly in communication and as the medium of instruction in education globally. To remain in line with this recognition, Malaysia's Ministry of Education (MoE) has put the importance of learning the English language and emphasized the need for students to succeed in the language since in primary school years (Misbah et al., 2017). The shift two in the Malaysian Education Blueprint 2013-2025 outlined the need for every child to be proficient in both 
Bahasa Malaysia and English language, at the same time is encouraged to learn an additional language (Malaysia Education Blueprint, 2013). Besides that, to cope with the current and future demands, the blueprint also outlined bilingual skills as one of the six student aspirations in which each student is expected to possess (Shan et al., 2016).

To realize this, the students must first acquire literacy as it offers many educational benefits for bilingual children (Eisenchlas, Schalley, \& Guillemin, 2013). According to Artieda (2017), among the early literacy skills is fundamentally involved in reading development (Suggate et al., 2018). It is among the most significant academic tasks the students embark on during their primary school years (Walgermo et al., 2018) since they depend mostly on the reading input in learning the language. Hence, the students who acquired reading skills from the early years of primary school are more likely to embark on a good start.

Being among the essential skill for academic achievement, reading is often seen as an interactive process between a reader and a text, which results to fluency in reading (Hesham Suleiman Alyousef, 2006). Among the processes are inferring, knowing correct sounds and comprehension. During these processes, the reader interacts dynamically with the text by employing various knowledge as he tries to licit the text's meaning (Hesham Suleiman Alyousef, 2006). In English language leaning, the process of reading enables the students to extract meaning from written or printed language (Muhamad et al., 2019).

Since reading plays a vital role in English language proficiency (Floyd et al., 2007) the Malaysia Education Blueprint 2013-2025 highlighted reading skills as one of the essential skills in ESL teaching and learning (Ishak \& Mohamad, 2018). Reading assessment is one of the factors that influence the ability to develop students' reading skills. Assessment is basically a series of processes by which judgments are made about the learner's language learning, abilities, knowledge, and accomplishments (Rethinasamy, 2013). Mermelstein (2015) argued that continuous assessment is a crucial factor associated with students' success in reading. Therefore, reading assessment should be fully utilised to help the students to continually improve their reading that will eventually enhance their English language proficiency.

On top of that, Malaysia strives to climb above the global average and be among the top one-third of the countries participating in the Program for International Student Assessment (PISA) (Chin, 2019). Reading skill is among the skills that are being tested in PISA. Due to this, reading assessment is taken into serious deliberation in implementing classroom-based assessment. Therefore, Classroom-Based Assessment is an excellent way for teachers to acquire students' information on their ESL reading and progress besides offering great advantages to students' language learning (Lan \& Fan, 2019).

The obligation lies greatly on the teachers on how they practice and utilize the reading assessment in the classroom-based setting. This practice involves the steps and measures taken by teachers during the assessment (Rethinasamy, 2013). 
These steps and measures include the planning, executing, and grading, as well as the documentation of the results of the classroom-based reading assessment. Past studies on teacher assessment practices are mainly concerned with defining the essential steps involved in successful assessment production (Rethinasamy, 2013). However, due to challenges faced when implementing a classroom-based reading assessment, the teachers were inclined to choose the summative assessment method compared to a more formative or alternative assessment.

This study of teachers' practices on classroom-based reading assessment would give the teachers the exposure on the types of classroom activities that are effective for the teachers to access pupils' reading (Marchand \& Furrer, 2014). This would enable them to improve their reading skills assessment practices, which can help in the betterment of classroom learning (Zhang \& Burry-Stock, 2003). Apart from that, teachers' understanding, principles, views and insights are closely related to their assessment practices reform (Lumadi, 2013).

The experience obtained corresponding with the perceived views from this study would further aid in gathering new information for improvement and provide a simple outline for a more in-depth future work for other academics who are interested to explore similar subject areas. Knowing educators' challenges in implementing classroom-based reading assessment would be useful for researchers to help other teachers in improving their practices in Malaysian classroom (Johari \& Abdul Aziz, 2019) especially when there is no detailed result given to the test other than a grade assigned to summarise the students' performances. As a result, the transformation of reading assessment from summative to classroom-based setting will give the opportunity for the pupils to be able to practise the reading skills and improve their reading as a whole.

This literature review will attempt to provide answers to the following research questions:

- What are the methods used by the ESL educators in practicing classroombased reading assessment?

- What are the challenges faced by the ESL educators in implementing classroom-based reading assessment?

\section{Literature Review}

\subsection{An Overview of Assessment Reform in the Malaysian Education System}

Evaluation and exams in Malaysia, as in many Asian countries, used to be considered as highly relevant (Nurul-Awanis et al., 2011). However, this system is seen as too examination-oriented and has failed to provide a holistic education. This is because learning nowadays are more learner-centred in which students need to play an active role in learning and assessment to construct their knowledge and skills (Nicol, 1997; Barr \& Tagg, 1995). Hence, the introduction of CEFR has brought a new era to the curriculum, teaching and learning, and language assessment (Mohd Don \& Abdullah, 2019). 
Under the education reform, a more precise descriptor which is the "can-do" descriptor, is used for common reference in specifying the learning outcomes in all language skills, including reading skills. This enables both the teachers and the ESL learners to set their aim of what they want to achieve and move towards it (Ministry of Education, 2016). Besides, Malaysia strives to climb above the global average and be among the top one-third of the countries participating in the Program for International Student Assessment (PISA) (Chin, 2019). The PISA-based Test is a voluntary assessment in which measures 15 -year-old students' performance, and one of them is in reading performance. OECD (2019) reported that more than $50 \%$ of learners in Malaysia acquired a minimum level 2 reading ability. This level indicated that the students could at least identify the key idea in a medium-length text, identify information based on basic but often complicated parameters, and reflect when channelling on the purpose and document type. Malaysian learners' PISA result also rose in 2018 compared with 2012, rising to 415 in 2018 compared to 398 in 2012.

Due to this, it is believed the CEFR-embedded syllabus and assessment form become a prominent feature in the reform of the English language education in Malaysia. Since both assessments are grounded on the same framework, hence the outcomes are comparable. It can benchmark the performance with that of national education systems from around the world. This increase the chance of realising the aim to reach the top tier country in worldwide assessment in PISA within 15 years (Ministry of Education, 2015).

For that reason, the only way to compete with the global assessment form is to change the assessment form. Therefore, the replacement of the summative test with a more objective system, which is classroom-based assessment (CBA), is one of the initiatives to improve the assessment form (Mohd Pilus, 2019). The classroom-based assessment is an assessment performed by the teachers in the classroom (Black \& Wiliam, 1998). It offers a wide range of assessment instead of summative test, where the students can be assessed through the classroom activities comprising games, simple projects, role-playing, storytelling and quizzes to enable the pupils to improve their talent, interest, skills and personality. In language teaching, Classroom-based assessment is used by teachers not only to attain students' information on second or foreign language acquisition and progress but to contribute to their language learning (Lan \& Fan, 2019). Hence, assessment for learning offers a different perspective to traditional assessment in schools. This is because the activities that are carried out by the teacher are designed to highlight the students' strengths and weaknesses and also to provide them with feedback that will further their learning (Earl, 2003).

According to Ahmad (2010), there are five principles to be taken into account in ensuring high-quality assessments. They are validity, reliability, objectivity, administration and interpretation. Compared to standardized testing in which merely reveal the students' test scores, classroom-based assessment gives an instant action of progress and accomplishment of students, guide and refine teach- 
ers' instruction, and analyze students' understanding of a topic. On top of that, classroom-based assessment provides a clear picture of students' strengths and flaws that can assists instruction and encourage individual development of the pupils (Jia, Eslami, \& Burlbaw, 2006). This allows teachers to determine where the students' position is in their learning development (Eng et al., 2016).

\subsection{Educators Practices in Classroom-Based Reading Assessment}

Rethinasamy (2013) referred assessment practices as the measures and procedures taken by teachers during the reading assessment. These assessment procedures start from the planning, executing and scoring of the assessment, up to the documentation and reporting of the results of the assessment. However, the study of the assessment practices of ESL teachers and instructors particularly in reading skills are rather limited. Similarly most of the study that claimed to examine teachers' assessment practices were simply investigating the views of teachers as a whole (Rethinasamy, 2013).

Cheng et al., (2004) in their comparative study investigated the classroom-based assessment practices by looking at the purposes, methods and procedures used by the universities instructors in ESL classroom. This study involved 267 ESL English instructors at tertiary levels in Hong Kong, Canada and China. The result of the survey showed that most of the instructors in Canada and Beijing use assessment results to plan their instruction regardless of language skills in the preparation of students for standardized tests such as the TOEFL. As for the methods of assessment, it is reported that reading summary and short-answer items were the most preferred methods used by the instructors in Canada and Hong Kong when assessing students' reading. In contrast, various formatted assessment methods like multiple-choice items and standardized reading tests preferred by the instructors from Beijing. To assess the students' reading to a greater degree, it was found that the instructors in all targeted countries favoured the student-constructed assessments, such as student journals and portfolios. Moving to the forms of feedback, oral feedback was reported to be the most common form of feedback given to students during their courses. Nevertheless, the outcomes indicated that the teachers used the assessment primarily to inform the instruction. However, the research did not consider whether the teachers were really practising what they had claimed or learned.

According to Rodriguez (2004), classroom assessments are one of the indicators of educational outcomes that help to produce the desired outcomes. Hao \& Johnson (2013) conducted an international study involving fourth graders' teachers from three English speaking countries which are Canada, New Zealand, England and America. This study had adopted a modified Brookhart model to investigate the relationship between teachers' classroom assessment practices and students' reading literacy achievement based on three characteristics of scores, which are a) reading for literary experience; b) reading for acquiring and using in-formation; and c) overall reading literacy. In this study, the assessment 
practices focused on the methods, types, or forms of reading assessments. On top of that, the PIRLS Teachers Questionnaire was used to identify teachers' different assessment practices in the classroom. The PIRLS assessment emphases on student achievement in reading literacy. Hence, the overall reading literacy achievement's data were obtained from PIRLS student assessment in this study.

The study revealed that the teachers in Canada, New Zealand, and America regularly used paper-based assessment methods such as multiple-choice items, short-answer and paragraph writing instead of oral communication in classroom-based reading assessment. On the other contrary, the teachers in England preferred to utilise both paper and pencil-based and oral communication when assessing their students' reading. However, statistical analysis suggested a null result, which indicated that there was little evidence to support the association between teachers' methods of classroom reading assessment and students' reading literacy. Considering the limitations of the study, hence generalisation on the result of the study could not be made.

Prior studies discussed earlier emphasis mainly on instructors and teachers assessment practices at the international level. As for ESL teachers in Malaysia, Mansur \& Abd Samad (2015) conducted a study to explore the lower primary school teachers' preferences in the methods of classroom-based reading assessment. This study involved teachers from six different schools in Kuala Lumpur, Malaysia, using a survey questionnaire and oral interview as the main instruments. From the result, it was discovered that $46.67 \%$ of teachers favoured Multiple Choice Questions (MCQ) examination format to assess students' reading comprehension skills. It was followed by WH-Question format and the least, Yes/No Question and True/False Question. These formats indicated that the teachers in this study mainly used paper and pencil-based approach when assessing students' reading.

In looking at the reasons of why these formats were preferred, the result of the interview revealed that the teachers frequently used the MCQ format because they believed it was easier for them to define the scores through the number of correct answers. The format was more accessible for the students, especially for primary level compared to other formats. As part of their attempts to support students with low English language proficiency, the teachers also created questions with four answers options. However, in reference to Vygotsky's (1978) sociocultural theory, teachers have to formulate questions that make students go beyond giving easy, short-specific answers and also make them think and focus on the topic, rather than merely discovering the correct response given their age factor in order to make their learning more enjoyable and also test their creative thinking minds. As a whole, this study again primarily emphasis on the teachers' perceptions of reading assessment formats, little is known about their assessment strategies and what is the process involved when implementing the classroom-based reading assessment. 


\subsection{Challenges in Implementing Classroom-Based Reading Assessment}

Although previous studies has outlined a number of benefits of classroom-based assessment, yet the challenges of implementing this assessment is still exists.

One of the challenges in implementing classroom-based assessment on reading is the negative perceptions. It is believed that teachers' beliefs and attitudes influence their assessment and evaluation practices (Breen et al., 1997). Hence, understanding the instincts and beliefs of teachers is critical, since teachers have a strong presence throughout the reading assessment process. Veloo et al., (2016) discovered that more than half percent of the teachers hardly practiced classroom-based assessment because they viewed it as not being helpful to the students. This explains why they practice limited classroom-based assessment because the practices merely to fulfil the SBA (School Based Assessment) obligation in which to determine students' bands instead of recognizing students' learning development or planning teaching. This perception may be due to the teachers' limited awareness on the benefits of classroom-based reading assessment and insufficient knowledge about it (Uri \& Aziz, 2018). Hence, the concerns raised that hold back the introduction of classroom-based reading assessment into education was their own resistance towards the new framework, lack of training in classroom-based reading assessment and negative perceptions of classroom-based reading assessment.

Moreover, another issue regarding classroom-based reading assessment is the large number of students in the class (Raman \& Yamat, 2014). Generally, the public schools in Malaysia are crammed with students with each classroom needs to accommodate about thirty-five and above. The atmosphere in the noisy learning setting made it difficult to incorporate classroom-based reading assessments. The concern is how the teachers will assess the students' reading in such environment where so many students were in one class. This brings up the issues of the educators' different perceptions of assessment and rating, as there would be several different forms of assessment that educators might carry out, and whether one assessment should be made for the entire class, or a distinction style assessment where students would be assessed according to their own level of skill. The concerns that will arise would be what kind of information the educator would provide to support her judgment that the evaluation decision is accurate, and this makes classroom-based assessment difficult to perform (Smith, 2003).

\section{Conclusion and Implications}

Previous research on the area of practices and perceptions of classroom-based assessment is an essential guide to the researcher on the need for classroombased reading assessment pertaining to methods to be incorporated into the teaching process. The implementation of classroom-based reading assessment frequently faces challenges on how to carry out the assessment, how teachers view the classroom-based assessment and other additional issues such as lack of 
basic knowledge among teachers and the issue of reliability and lack of resources.

The most significant finding from this review is that different types of assessment practices can contribute to students' learning and that the effectiveness of optimal assessment approaches can be specific rather than universal. The finding showed that different competencies in teacher assessment resulted in variation in teacher reading assessment tasks, which further influenced student learning. Hence, teachers' development in reading assessment should be encouraged and carried out more systematically. This professional development is crucial in ensuring that teachers are well equipped with assessment knowledge, particularly in classroom-based setting.

In addition, more detailed guidance addressing reading assessments for both progress and achievement-based purposes is deemed necessary. Previous studies showed that teachers prefer to practise what they believe are right, with little proper guidance to rely on as a reference. The Ministry of Education could revise and suggest a more formative assessment framework that aimed at improving teaching and student learning.

On top of that, in order to ensure the smoothness and efficiency of the implementation of a classroom-based reading assessment, teachers should be equipped with appropriate skills not only in designing assessment instruments, conducting tests and giving grades but also utilizing and presenting test results. The implications of this study are directed at the three leading organisations, namely Ministry of Education (MoE), State Education Department (JPN) and District Education Department (PPD), educational agencies, school and teacher curriculum leaders.

\section{Conflicts of Interest}

The authors declare no conflicts of interest regarding the publication of this paper.

\section{References}

Ahmad, M. F. (2010). Amalan Pentaksiran Pengajaran dan Pembelajaran di Kolej Komuniti di Negeri Johor. In Prosiding Seminar Transformasi Pendidikan Teknikal anjuran Center for Testing, Measurement \& Appraisal (CeTMA) (pp. 152-159). Universiti Utara Malaysia.

Alyousef, H. S. (2006). Teaching Reading Comprehension to ESL/EFL Learners. Journal of Language and Learning, 5, 379-380.

Artieda, G. (2017). The Role of L1 Literacy and Reading Habits on the L2 Achievement of Adult Learners of English as a Foreign Language. System, 66, 168-176. https://doi.org/10.1016/j.system.2017.03.020

Barr, R. B., \& Tagg, J. (1995). A New Paradigm for Undergraduate Education. Change, 27, 13-25. https://doi.org/10.1080/00091383.1995.10544672

Black, P., \& Wiliam, D. (1998). Assessment and Classroom Learning. Assessment in Education, 5, 7-71. https://doi.org/10.1080/0969595980050102

Breen, M. P., Barratt-Pugh, C., Derewianka, B., House, H., Hudson, C., Lumley, T., \& 
Rohl, M. (1997). Profiling ESL Children: How Teachers Interpret and Use National and State Assessment Frameworks. Canberra City: Department of Employment, Education, Training and Youth Affairs.

Cheng, L., Rogers, T., \& Hu, H. (2004). Language Testing.

Chin, C. (2019). The Star Online.

https://www.thestar.com.my/news/nation/2019/12/17/malaysia-on-course-to-break-int o-pisa039s-top-30

Earl, L. (2003). Assessment as Learning: Using Classroom Assessment to Maximize Student Learning. Thousand Oaks, CA: Corwin Press.

Eisenchlas, S. A., Schalley, A. C., \& Guillemin, D. (2013). The Importance of Literacy in the Home Language: The View from Australia. Sage Open, 3, 2158244013507270. https://doi.org/10.1177/2158244013507270

Eng, L. S., Mohamed, A. R., \& Ismail, S. A. M. M. (2016). Systematic Tracking of Malaysian Primary School Students' ESL Reading Comprehension Performance to Facilitate Instructional Processes. International Journal of Instruction, 9, 149-162.

https://doi.org/10.12973/iji.2016.9112a

Floyd, R. G., Keith, T. Z., Taub, G. E., \& McGrew, K. S. (2007). Cattell-Horn-Carroll Cognitive Abilities and Their Effects on Reading Decoding Skills: G Has Indirect Effects, More Specific Abilities Have Direct Effects. School Psychology Quarterly, 22, 200-233. https://doi.org/10.1037/1045-3830.22.2.200

Hao, S., \& Johnson, R. L. (2013). Teachers' Classroom Assessment Practices and FourthGraders' Reading Literacy Achievements: An International Study. Teaching and Teacher Education, 29, 53-63. https://doi.org/10.1016/j.tate.2012.08.010

Ishak, W. I. W., \& Mohamad, M. (2018). The Implementation of Common European Framework of References (CEFR): What Are the Effects towards LINUS Students' Achievements? Creative Education, 9, 2714-2731.

https://doi.org/10.4236/ce.2018.916205

Jia, Y., Eslami, Z. R., \& Burlbaw, L. M. (2006). ESL Teachers' Perceptions and Factors Influencing Their Use of Classroom-Based Reading Assessment. Bilingual Research Journal, 30, 407-430. https://doi.org/10.1080/15235882.2006.10162883

Johari, N. A., \& Abdul Aziz, A. (2019). Teachers' Perception on Using the Pulse 2 Textbook. Journal of Educational Research and Indigenous Studies, 2, 1-15

Lan, C., \& Fan, S. (2019). Developing Classroom-Based Language Assessment Literacy for In-Service EFL Teachers: The Gaps. Studies in Educational Evaluation, 61, 112-122. https://doi.org/10.1016/j.stueduc.2019.03.003

Lumadi, M. W. (2013) Challenges Besetting Teachers in Classroom Assessment: An Exploratory Perspective. Journal of Social Sciences, 34, 211-221. https://doi.org/10.1080/09718923.2013.11893132

Malaysia Education Blueprint (2013). Malaysia Education Blueprint 2013-2025. Education, 27, 1-268.

Mansur, U., \& Abd Samad, A. (2015). Views of Educators: Assessment Preference in Reading Skills for Malaysia Primary School. International Journal of Information and Communication Technology Research, 5, 35-43.

Marchand, G. C., \& Furrer, C. J. (2014). Formative, Informative, and Summative Assessment: The Relationship among Curriculum-Based Measurement of Reading, Classroom Engagement, and Reading Performance. Psychology in the Schools, 51, 659-676. https://doi.org/10.1002/pits.21779

Mermelstein, A. D. (2015). Reading Level Placement and Assessment for ESL/EFL Learn- 
ers: The Reading Level Measurement Method. ORTESOL Journal, 32, 44-55.

Ministry of Education (2015). Malaysian Education Blueprint Annual Report 2014. https://www.padu.edu.my/wp-content/uploads/2018/01/PADU-ENG-LoRes-Full.pdf

Ministry of Education (2016). Common European Framework of Reference for Languages (CEFR): English Language Handbook for Primary School Teachers. Ministry of Education Malaysia.

Misbah, N. H., Mohamad, M., Yunus, M. M., \& Ya'acob, A. (2017). Identifying the Factors Contributing to Students' Difficulties in the English Language Learning. Creative Education, 8, 1999-2008. https://doi.org/10.4236/ce.2017.813136

Mohd Don, Z., \& Abdullah, M. H. (2019). The Reform of English Language Education in Malaysia.

https://www.freemalaysiatoday.com/category/opinion/2019/05/22/the-reform-of-englis h-language-education-in-malaysia/

Mohd Pilus, F. A. (2019). Abolishment of Examination, to Focus on Potential Students Diversity. New Straits Times.

https://www.nst.com.my/news/nation/2019/01/447605/abolishment-examination-focus -potential-students-diversity

Muhamad, S. N., Azmi, M. N. L., \& Hassan, I. (2019). Reading Interest and Its Relationship with Reading Performance: A Study of English as Second Language Learners in Malaysia. Humanities and Social Sciences Reviews, 7, 1154-1161. https://doi.org/10.18510/hssr.2019.76165

Nicol, D. J. (1997). Research on Learning and Higher Education Teaching. UCoSDA Briefing Paper 45, Sheffield: Universities and Colleges Staff Development Agency.

Nurul-Awanis, A. W., Hazlina, A. H., Yoke-May, L., \& Zariyawati, M. A. (2011). Malaysian Education System Reform: Educationists' Perspectives. In Proceeding of the International Conference on Social Science, Economics and Art 2011 (pp. 14-15). Putrajaya: Kemala Publisher.

OECD (2019). OECD PISA 2018 Results Volume I. https://www.oecd.org/pisa/Combined Executive Summaries PISA 2018.pdf

Raman, K., \& Yamat, H. (2014). English Teachers' Voices on the Challenges of the School Based Assessment. Frontiers of Language and Teaching, 5, 66-73.

Rethinasamy, S. (2013). English Language Assessment in Malaysia: Teachers' Practices in Test Preparation. Issues in Language Studies, 2, 24-39. https://doi.org/10.33736/ils.1669.2013

Rodriguez, M. C. (2004). The Role of Classroom Assessment in Student Performance on TIMSS. Applied Measurement in Education, 17, 1-24. https://doi.org/10.1207/s15324818ame1701 1

Shan, P. L. M., Yunus, M. M., \& Mohamad, M. (2016). Its Effects on English Language Teaching in Malaysia. Asian EFL Journal, 4, 158-171.

Smith, J. K. (2003). Reconsidering Reliability in Classroom Assessment and Grading. Educational Measurement: Issues and Practice, 22, 26-33. https://doi.org/10.1111/j.1745-3992.2003.tb00141.x

Suggate, S., Schaughency, E., McAnally, H., \& Reese, E. (2018). From Infancy to Adolescence: The Longitudinal Links between Vocabulary, Early Literacy Skills, Oral Narrative, and Reading Comprehension. Cognitive Development, 47, 82-95. https://doi.org/10.1016/j.cogdev.2018.04.005

Uri, N. F. M., \& Aziz, M. S. A. (2018). Implementation of CEFR in Malaysia: Teachers' Awareness and the Challenges. 3L: Language, Linguistics, Literature, 24, 168-183. 
https://doi.org/10.17576/3L-2018-2403-13

Veloo, A., Ramli, R., \& Khalid, R. (2016). Assessment Practices among English Teachers in Malaysian Secondary Schools. International Journal for Infonomics, 9, 1220-1227. https://doi.org/10.20533/iji.1742.4712.2016.0149

Vygotsky, L. S. (1978). Mind in Society: The Development of Higher Psychological Processes. Cambridge, MA: Harvard University Press.

Walgermo, B. R., Frijters, J. C., \& Solheim, O. J. (2018). Literacy Interest and Reader Self-Concept When Formal Reading Instruction Begins. Early Childhood Research Quarterly, 44, 90-100. https://doi.org/10.1016/j.ecresq.2018.03.002

Zhang, Z., \& Burry-Stock, J. A. (2003). Classroom Assessment Practices and Teachers' Self-Perceived Assessment Skills. Applied Measurement in Education, 16, 323-342. https://doi.org/10.1207/S15324818AME1604 4 